\title{
Biological efficiency of Charolais beef cows of different body sizes
}

\author{
Eficiência biológica de vacas de cria Charolês de diferentes \\ tamanhos corporais
}

\author{
Gustavo Duarte Farias ${ }^{*}$; Liliane Cerdótes ${ }^{2}$; Ricardo Zambarda $\mathrm{Vaz}^{3}$; \\ João Restle ${ }^{4}$; Marcia Ferreira Bitencourt ${ }^{5}$; Dari Celestino Alves Filho ${ }^{6}$; \\ Ivan Luiz Brondani ${ }^{6}$
}

\begin{abstract}
This study aimed to evaluate the production, reproductive performance, and productive efficiency of predominantly Charolais cows and their calves (Straightbred, 3/4 C, 1/4 N) according to body size at calving. Sixty-three cow-calf pairs were used and classified into three weight groups: Light $(331.3 \pm 5.8$ $\mathrm{kg})$, Moderate $(385.9 \pm 5.3 \mathrm{~kg})$, and Heavy $(424.4 \pm 6.2 \mathrm{~kg})$. The classes were formed using half standard deviations above or below the average weight of the cows at calving. For each pair, the body weight was evaluated at calving, at weaning (63 days), at the beginning and at end of the reproductive period, and at 9 months for the calves. Pregnancy rates were similar $(P>0.05)$ between weight groups. The calves did not differ $(\mathrm{P}>0.05)$ in terms of body weight and weight gain from calving until pregnancy diagnosis ( 210 days). The heavy cows had greater weight variations from 210 days to 270 days than the light cows. The calf production rate (kg calf/cow kept in herds) did not differ between weight groups. However, in relation to the weight of the cows at 210 days, light cows were $11.28 \%$ and $13.02 \%$ more productive $(\mathrm{P}<0.05)$, than moderate and heavy cows, respectively. Light cows were more efficient than the other classes of cows at calving and at 210 days old. Our simulations showed that there were more kilograms for sale in herds of light cows $(53.085 \mathrm{~kg})$ than moderate and heavy cows (52.310 and $52.870 \mathrm{~kg}$, respectively), while maintaining the structures of the herd constant. The size of the Charolais cow did not influence the weight of calves from calving until 7 months of age or their reproductive performance provided they were weaned early. The need for space for the maintenance of the cow-calf pair increased as the weight of the cows increased. In herds with smaller cows, higher numbers and a higher production of weight for sale are observed than in herds with moderate and heavy cows. Light cows were the most efficient at calving and during pregnancy diagnosis at 210 days.
\end{abstract}

Key words: Animal production. Beef calves. Lactation. Weaning.

1 Discente, Curso de Doutorado do Programa de Pós-Graduação em Zootecnia, Universidade Federal do Rio Grande do Sul, UFRGS, Porto Alegre, RS, Brasil. E-mail: gustavo.dfarias@hotmail.com

2 Prof ${ }^{a}$, Departamento de Zootecnia, Instituto Federal Sul-Rio-Grandense, IFSUL, Bagé, RS, Brasil. E-mail: lilianecerdotes@ ifsul.edu.br

3 Prof., Departamento de Zootecnia, Universidade Federal de Pelotas, UFPEL, Pelotas, RS, Brasil. E-mail: rzvaz@terrra.com.br

4 Prof., Programa de Pós-Graduação em Zootecnia, Universidade Federal de Goiás, UFG, Goiânia, GO, Brasil. E-mail: jorestle@ terra.com.br

5 Discente, Curso de Mestrado, Programa de Pós-Graduação em Zootecnia, Universidade Federal de Pelotas, UFPEL, Pelotas, RS, Brasil. E-mail: mbvaz@hotmail.com

6 Profs., Departamento de Zootecnia, Universidade Federal de Santa Maria, UFSM, Santa Maria, RS, Brasil.E-mail: darialvesfilho@ hotmail.com; ivanbrondani@gmail.com

* Author for correspondence 


\section{Resumo}

Este estudo teve como objetivo avaliar a produção, desempenho reprodutivo e eficiência produtiva de vacas de cria com predominância Charolês (Puras e 3/4 C, 1/4 N) e seus bezerros de acordo com seu tamanho corporal no parto. Foram utilizados sessenta e três pares de vaca:bezerro classificadas em três grupos de pesos: Leves $(331,4 \pm 5,8 \mathrm{~kg})$, Moderadas $(385,9 \pm 5,3 \mathrm{~kg})$ e Pesadas $(424,3 \pm 6,2 \mathrm{~kg})$. As classes foram formadas com meio desvio padrão acima ou abaixo da média geral de peso das vacas ao parto. Para cada par, o peso corporal foi avaliado ao parto, no desmame (63 dias), no início e no final do período reprodutivo e nos bezerros aos nove meses de idade. As taxas de prenhez foram semelhantes ( $\mathrm{P}$ $>0,05)$ entre os grupos de peso. Os bezerros não diferiram $(\mathrm{P}>0,05)$ em peso e ganho de peso corporal do parto até os 210 dias. Os bezerros das vacas Pesadas apresentaram maiores variações de peso dos 210 aos 270 dias se comparados às vacas Leves. $\mathrm{O}$ índice de produção de bezerro (kg de bezerro/ vaca mantida) não diferiu. No entanto, ao relacioná-lo ao peso das vacas aos 210 dias, as vacas Leves forma mais produtivas $(\mathrm{P}<0,05)$, com aumento em 11,28 e 13,02\% na produção de bezerro quando comparada às vacas Moderadas e Pesadas, respectivamente. Vacas Leves foram mais eficientes ao parto e aos 210 dias. Através de simulação, verificaram-se mais quilos passíveis de venda no rebanho de vacas Leves (53.085 kg) comparado aos grupos Moderadas e Pesadas (52.310 e $52.870 \mathrm{~kg}$, respectivamente), mantendo as estruturas do rebanho constante. $O$ tamanho da vaca Charolês não influencia o peso do terneiro do parto aos sete meses de idade, nem o desempenho reprodutivo das mesmas, desde que desmamadas precocemente. A necessidade de área para a manutenção do par vaca:bezerro é crescente conforme o aumento do peso das vacas. Nos rebanhos com vacas menores, foi estimado maior número de matrizes e uma maior produção de peso para venda comparado às vacas Moderadas e Pesadas. As vacas Leves foram mais eficientes do parto aos 210 dias.

Palavras-chave: Bovinos de corte. Desmame. Lactação. Produção animal.

\section{Introduction}

Breeding and new rearing herds have low productivity due to an inadequate use of available resources resulting in low reproductive efficiency and kilogram productivity per cow kept in herds.

For increased efficiency, the type of animal should be matched to the food available and available technologies should be better applied so that food does not become insufficient for production. However, in many situations, the introduction of food technologies is hindered by costs and the difficulty in implementation. The producer must then seek animals most suitable for nutrition, health, and climatic adversities.

The efficiency of breeding herds can be improved through early weaning (VAZ; LOBATO, 2010), adjusting the available forage (FAGUNDES et al., 2003), use of cultivated grasslands and adapted genetic groups (ÍTAVO et al., 2014; VAZ et al., 2014), adjustment of the calving season, increased body condition scores, and selection of cow age (VIEIRA et al., 2005).

Another factor that may improve the performance of breeding herds is body structure. This is because it is related to the production demand of the animal. Its evaluation in cattle is an important criterion for the selection of more efficient herds. The selection for higher body growth efficiency characterizes animals with high maintenance costs (SILVA et al., 2015). With this, low reproductive rates and increases in age at puberty are observed (REGATIERI et al., 2012).

The determination of individual cow efficiency with weaning, evaluated by the percentage ratio between calf and cow weights, is an important tool as it reflects the advantages of a particular animal type, size, and breed in a specific environment (VAZ et al., 2016; LEMES et al., 2017).

During breeding, efficiency is related to the cow's ability to produce one calf per year, and its 
maternal ability will be reflected in the weaning weight of the offspring. However, in order to analyze herd efficiency, in addition to calf weight, the relationship to cow weight and the subsequent reproduction thereof must be taken into account (VAZ et al., 2014). Reproduction must be linked to efficiency due to a change in nutrients' priority at each physiological state of the animal.

Success in choosing the biological type depends on the appropriate combination of production potential and requirements of the animal category, availability of nutrients, and the type of environment where the system will be implemented. In stressfree environments where food is abundant, better productive and economic responses can be obtained with larger animals (BARBOSA, 2006). In adverse conditions, where resources are scarce, animals with a moderate body structure are preferred. The aim of this study was to evaluate the productive efficiency of predominantly Charolais cows during lactation according to their body size at calving.

\section{Material and Methods}

This study was conducted at the Beef Cattle Unit of the Department of Animal Sciences of the Federal University of Santa Maria, located in the Central Depression of Rio Grande do Sul, Brazil.

Performance and productivity data of 63 pairs of predominantly Charolais cows (Straightbred, 3/4 C $1 / 4 \mathrm{~N}$ ) and their calves were evaluated in a breeding herd from birth until early weaning and during backgrounding until calves were 9 months old. The cows were aged between 3 and 12 years. This effect was minimized with an equal distribution of ages in each weight groups.

Three groups were formed based on the weight differences between cows due to an average standard deviation $(42.0 \mathrm{~kg})$. They were divided, according to weight, into "Light" (weight is less than or equal to half the standard deviation below the mean: cows $\leq 362 \mathrm{~kg}$ ), "Moderate" (weight greater than half the standard deviation below the average and less than or equal to half the standard deviation above the mean: cows weighing more than $362 \mathrm{~kg}$ and less than $\leq 404 \mathrm{~kg}$ ) and "Heavy" (animals weighing more than half the standard deviation above the mean: cows weighing more than $404 \mathrm{~kg}$ ).

All animals were maintained under the same management and environment conditions during the lactation period. The food was composed of native pasture (NP) with a stocking rate of 0.9 cows with calves $\mathrm{ha}^{-1}$ associated with a mineralization consistent with the requirements of the categories. The availability of herbage mass was determined by the double sampling technique. The botanical composition of the region's natural pastures was diverse. Composite vegetation is interspersed with grasses. This vegetation, when well-managed, does not leave bare ground because the rhizomatous extract is abundant and is represented by Paspalum notatum, on tops and slopes of grassy hills, and by stoloniferous Axonopus fissifolius) in humid lowlands. The Andropogon lateralis stands out as a superior extract. Among legumes, there are clovers with a great emphasis on family Desmodium. In overgrazing, there is a decrease in this plant community, increasing the number of composites, such as Soliva pterosperma and Vernonia nudiflora. Lately, the Eragrostis Plana Nees has been spreading (PILLAR et al., 2009).

Cows and calves were weighed within 24 hours after calving, at 63 days postpartum, at the start and end of the breeding season, and during pregnancy diagnosis (210 days). The calves were also weighted at an average age of 270 days. The daily weight variations were determined as a function of the difference between weights divided by the number of days between weightings. On weighing days, the evaluation of the body condition score was also performed by assigning values within a range 1-5 (1 $=$ very thin, $2=$ thin, $3=$ average, $4=$ fat, and $5=$ very fat) (FERREIRA et al., 2013).

After weaning, cows remained in the same area, 
but with a reduction in area to keep the stocking rate at $0.9 \mathrm{AU} \mathrm{ha}^{-1}$. After the stress of weaning and the period that they remained in the corral, calves were also kept under the same stocking rate on a natural pasture, receiving food supplementation through a balanced concentrate according to each category $(18 \% \mathrm{CP}$ and $70 \% \mathrm{TDN})$ at $1 \%$ of their body weight until 210 days.

To evaluate the estimated cow milk production, the direct method was used with hand milking. The day before the evaluation, the calves were separated from cows at $14 \mathrm{~h} 00$, and at $18 \mathrm{~h} 00$, they were paired with the cows for a period of about 20 minutes. This method was intended to exhaust the cow udder. After nursing, the calves were again separated from their mothers until the next morning. During the night, calves were kept in a corral where they had free access to water, while cows remained on pasture with sufficient forage and water. At 06h00 the next day, the milking of the cows started by restraining them in a trunk. Milk production in 24 hours was estimated by the equation proposed by Restle et al. (2007):

$$
M P=\frac{(M M P * 2) * 60 \mathrm{~min} * 24 h .}{T N M}
$$

Where MP is milk production estimated for 24 hours on the day of milking ( $\left.\mathrm{kg} \mathrm{day}{ }^{-1}\right)$; MMP is mechanical milking production of two quarters of the udder; TNM is time in minutes between the last nursing and the milking. The evaluations to estimate the milk production of cows were made at 21,42 , and 63 days postpartum. Total milk production was estimated by adding the milk production of the three periods.

The reproductive management was natural breeding with $4 \%$ of bulls, comprising 90 days of mating. The bulls were previously tested for breeding soundness, fertility, and libido to determine reproductive fitness. Pregnancy diagnosis was performed 60 days after the end of the reproductive period using an ultrasound.
For productivity, the total weight gain of cows and calves $(\mathrm{kg})$ measured from calving until 210 days were considered. The productive efficiency of cows of different sizes was evaluated at birth and at 210 days, considering the amount of kilograms of calves at 210 days for every 100 kilograms of cows at calving and at 210 days, respectively (RIBEIRO et al., 2001).

The calf production index was calculated by associating calf weight at 210 days and cow pregnancy rate. The result was expressed in kilograms of calves produced per cows kept in the herd within 1 year (VAZ et al., 2010). Furthermore, productive efficiency analyses were performed according to land area for each cow-calf pair as a function of a fixed animal stocking rate of $0.9 \mathrm{AU}$ ha $^{-1}$.

For production efficiency of weight groups, a simulation of the area required to allocate the cowcalf pair of each group was made, with a stocking capacity of $0.9 \mathrm{AU} \mathrm{ha}{ }^{-1}$, where $1 \mathrm{AU}=450 \mathrm{~kg}$ of body weight. Consequently, considering a fixed area of 500 ha, the other categories were extrapolated as a function of the possible number of cows and of the remaining categories of a cow-calf breeding system, which sells male calves and the surplus of replacement heifers $(20 \%$ replacement of the breeding herd). The first mating of replacement heifers was held at 2 years of age. These data were acquired as a function of the number of cows in each group and their reproductive performance. The production and sales of livestock were calculated based on weight gain and the likely weights of adults in each group, as well as the weight gain achieved in this study.

The experimental design was completely randomized. An analysis of variance of the data, including the fixed effects of cow size in the mathematical model, was conducted. Cow age, calving order, and calf sex were used as covariates. The analyses were performed using the GLM procedure. The data were analyzed using the SAS 
statistical software, version 8.6 (SAS, 2001), adopting $5 \%$ as a maximum significance level using a " $t$ " test. The pregnancy rate was analyzed by ChiSquare.

\section{Results and Discussion}

The formation of groups based on the average standard deviation of weight determined groups with average weights of $331.3,385.9$, and $424.4 \mathrm{~kg}$ for Light, Moderate, and Heavy cows, respectively (Table 1). The body weights of cows differed $(\mathrm{P}<0.05)$ between weight groups from calving to 210 days.

The performance related to the average daily weight variation of cows in general was not influenced $(\mathrm{P}>0.05)$ by size. The behavior of daily weight variations from calving to 63 days, although without differences $(\mathrm{P}>0.05)$, showed positive weight variations for light $\left(0.015 \mathrm{~kg}\right.$ day $^{-}$ $\left.{ }^{1}\right)$ to moderate $\left(0.105 \mathrm{~kg} \mathrm{day}^{-1}\right)$ cows, but negative variations $\left(-0.033 \mathrm{~kg} \mathrm{day}^{-1}\right)$ for heavy animals.

The lower performances found from calving to 63 days showed that this period presents the biggest challenges for cows, namely, from calving to the peak of lactation. During this period, the feeding system may not contemplate all cows' nutritional requirements. Cows may then use their body reserves (VIEIRA et al., 2005), which can be observed by the negative variation in heavy cows. This result is reflected in a worse body condition in heavy cows 63 days postpartum $(\mathrm{P}<0.05)$, although, at the end of breeding, the body conditions of the three groups were similar.

Table 1. Adjusted means and standard errors for the development variables of Charolais cows with different body sizes and their calves.

\begin{tabular}{lccc}
\hline \multirow{2}{*}{ Description } & \multicolumn{3}{c}{ Body structures } \\
\cline { 2 - 4 } & Cows & Moderate & Heavy \\
\cline { 2 - 4 } Calving & Body weights and variations $(\mathrm{kg})$ & \\
63 days postpartum & $331.3 \pm 5.8^{\mathrm{c}}$ & $385.9 \pm 5.3^{\mathrm{b}}$ & $424.4 \pm 6.2^{\mathrm{a}}$ \\
End of breeding period & $332.2 \pm 7.7^{\mathrm{c}}$ & $392.5 \pm 7.0^{\mathrm{b}}$ & $422.3 \pm 8.2^{\mathrm{a}}$ \\
Weight 210 days postpartum & $348.0 \pm 7.3^{\mathrm{c}}$ & $413.6 \pm 6.6^{\mathrm{b}}$ & $443.1 \pm 7.7^{\mathrm{a}}$ \\
Variation from calving to 63 days & $384.6 \pm 8.8^{\mathrm{c}}$ & $450.9 \pm 8.0^{\mathrm{b}}$ & $481.5 \pm 9.3^{\mathrm{a}}$ \\
Variation from calving to 210 days & $0.015 \pm 0.063^{\mathrm{a}}$ & $0.105 \pm 0.060^{\mathrm{a}}$ & $-0.033 \pm 0.065^{\mathrm{a}}$ \\
& $0.253 \pm 0.032^{\mathrm{a}}$ & $0.306 \pm 0.029^{\mathrm{a}}$ & $0.271 \pm 0.034^{\mathrm{a}}$ \\
Calving & & & \\
63 days postpartum & $2.99 \pm 0.05^{\mathrm{a}}$ & $3.04 \pm 0.05^{\mathrm{a}}$ & $3.05 \pm 0.05^{\mathrm{a}}$ \\
End of breeding period & $3.04 \pm 0.06^{\mathrm{a}}$ & $3.09 \pm 0.05^{\mathrm{a}}$ & $3.05 \pm 0.06^{\mathrm{a}}$ \\
& $3.14 \pm 0.07^{\mathrm{a}}$ & $3.18 \pm 0.07^{\mathrm{a}}$ & $3.18 \pm 0.08^{\mathrm{a}}$ \\
& Calves & \\
Weight at calving & $32.1 \pm 1.3^{\mathrm{a}}$ & $34.7 \pm 1.2^{\mathrm{a}}$ & $34.9 \pm 1.4^{\mathrm{a}}$ \\
Weight at 210 days & $135.3 \pm 5.3^{\mathrm{a}}$ & $140.9 \pm 4.8^{\mathrm{a}}$ & $134.7 \pm 5.6^{\mathrm{a}}$ \\
Weight to 270 days & $140.9 \pm 5.8^{\mathrm{a}}$ & $151.5 \pm 5.2^{\mathrm{a}}$ & $147.7 \pm 6.1^{\mathrm{a}}$ \\
Variation from calving to 210 days & $0.518 \pm 0.028^{\mathrm{a}}$ & $0.556 \pm 0.026^{\mathrm{a}}$ & $0.537 \pm 0.030^{\mathrm{a}}$ \\
\hline
\end{tabular}

Means in lines followed by different letters differ at a $5 \%$ level by the $t$ test.

According to Santos et al. (2009), the evaluation of the body condition score is very important for decision-making within a production unit considering that cows with good scores at calving 
return to heat earlier and with higher conception rates, which positively affects pregnancy rates (FERREIRA et al., 2013).

Calves did not differ $(\mathrm{P}>0.05)$ in body weight and weight variations from calving to 7 months of age among cow weight groups (Table 1). After 7 months, calves born from heavy and moderate cows had higher daily weight variations than those born from light cows.

After weaning, when the animals become dependent solely on the food supplied to them without the influence of a maternal presence and the mother's milk production, more heavy than light adult animals tended to develop (OWENS et al., 1993). This is especially the case in Charolais animals because of selection during the development of the breed, when body growth is selected more intensely.

Cow pregnancy rates did not differ among weight groups, presenting values of $61.21,62.18$, and $67.63 \%$ for the light, moderate, and heavy groups, respectively (Table 2). Although, without differences $(\mathrm{P}>0.05)$, pregnancy rates are important because the biological efficiency of a female herd results from the production of kilograms of calves per cow exposed to reproduction (RIBEIRO et al., 2001) and/or kept in the herds (VAZ et al., 2010).

The average pregnancy rate of this study $(63.67 \%)$ is higher than the average values found in southern Brazil, which recorded values of $56.39 \%$ (SOUZA SILVA et al., 2014). The higher pregnancy repetition rates of the three groups are due to positive changes in cow weight gain, probably due to early weaning, relieving the cow from producing milk, which is exhausting and inhibits a subsequent reproduction (VAZ et al., 2010). The average pregnancy rate of this study (63.67\%), although favored by early weaning at 63 days, did not reach the average values obtained by this technique, which may reach more than $80 \%$ of pregnancy repetition (VAZ et al., 2010). This can be explained in part by animal stocking rate, which shows the infeasibility of new pregnancies and production of heavy calves (FAGUNDES et al., 2003). These authors showed that $0.8 \mathrm{AU} \mathrm{ha}^{-1}$ is not compatible with advanced livestock breeding techniques, obtaining $22.6 \%$ for reproduction rates.

In assessing the calf production index, which associates calve weights to cow pregnancy rates, there was no difference $(\mathrm{P}>0.05)$ among weight groups. The importance of this lies in the fact that, regardless of cow size, the production of kilograms of calves per cow kept in herds was similar. Thus, light cows consumed less food than moderate and heavy cows producing the same number of kilograms of calves. When comparing the weight groups of this study to their likely food consumptions, a greater demand was estimated for pasture offer (25\%), crude protein $(20 \%)$, and total digestible nutrients (17.9\%) during a 210-day lactation period in heavy cows than light cows (NRC, 2016).

After evaluating the calf production index adjusted for cow weight at 210 days, light cows were more efficient $(\mathrm{P}<0.05)$ than moderate and heavy cows, with 11.28 and $13.02 \%$ increases in the production of calves. Besides the choice of an animal size suitable to the conditions of the production system, the probable production of kilograms of calves per cow kept in breeding herds can be improved using technologies to increase the calving rate (VAZ et al., 2010) or the development of calves with improvements in the breeding herd feeding levels (VAZ et al., 2014).

Productive efficiencies at calving and 210 days that take into account calf weight at 210 days in relation to that at calving also showed greater efficiencies $(\mathrm{P}<0.05)$ of light cows in relation to the cows of the other weight groups, with increases of 13.07 and $13.38 \%$ and 29.9 and $24.91 \%$, Moderate and Heavy cows, respectively.

Summing the maintenance requirements from calving to 210 days, milk production and weight gain of cows in the three groups, the requirement was $1,044 \mathrm{~kg}$ of total TDN and $68.67 \mathrm{~kg}$ of CP. The 
highest production of calves per cow $(\mathrm{kg})$ for light cows was due to a lower demand for TDN and CP necessary for the production of these animals. The ratio between calf and cow weight was variable. As the weight of the cow increased, the ratio between calf kilogram per cow kilogram decreased. This ratio can be improved by using better nutritional levels in herds (RIBEIRO et al., 2001; VAZ et al., 2014) and more efficient technologies to increase calving rate (VAZ et al., 2010). This relationship may have an important impact on the breeding sector, especially because heavier cows are sometimes preferred by producers. The biological and productive results of herds are a consequence of the performance of categories associated with their consumption (RESTLE et al., 2007).

Table 2. Adjusted means and standard error for reproductive performance and production efficiencies of Charolais cows with different body sizes

\begin{tabular}{|c|c|c|c|}
\hline \multirow{2}{*}{ Description } & \multicolumn{3}{|c|}{ Body structures } \\
\hline & Light & Moderate & Heavy \\
\hline Pregnancy, \%* & $61.21^{\mathrm{a}}$ & $62.18^{\mathrm{a}}$ & $67.63^{\mathrm{a}}$ \\
\hline Calf production index, $\mathrm{kg}^{\mathrm{A}}$ & $82.7 \pm 3.3^{\mathrm{a}}$ & $87.7 \pm 3.0^{\mathrm{a}}$ & $91.1 \pm 3.5^{\mathrm{a}}$ \\
\hline Calf production index $/ \mathrm{kg}^{\mathrm{B}}$ & $21.7 \pm 0.8^{\mathrm{a}}$ & $19.5 \pm 0.8^{b}$ & $19.2 \pm 0.9^{b}$ \\
\hline Production efficiency at calving, $\mathrm{kg}^{\mathrm{C}}$ & $41.5 \pm 1.7^{\mathrm{a}}$ & $36.7 \pm 1.5^{b}$ & $32.1 \pm 1.8^{\mathrm{c}}$ \\
\hline Production efficiency at 210 days, $\mathrm{kg}^{\mathrm{D}}$ & $35.6 \pm 1.4^{\mathrm{a}}$ & $31.4 \pm 1.2^{\mathrm{b}}$ & $28.5 \pm 1.4^{\mathrm{c}}$ \\
\hline Milk production up to 63 days, liters & $192.2 \pm 17.0^{\mathrm{b}}$ & $261.9 \pm 15.5^{\mathrm{a}}$ & $227.9 \pm 18.1^{\mathrm{ab}}$ \\
\hline Weight gain of the pair cow-calf, $\mathrm{kg}$ & $156.7 \pm 8.3^{\mathrm{a}}$ & $171.2 \pm 7.5^{\mathrm{a}}$ & $156.9 \pm 8.8^{\mathrm{a}}$ \\
\hline Real occupation up to 210 days, $\mathrm{ha}^{\mathrm{E}}$ & $1.07 \pm 0.02^{\mathrm{c}}$ & $1.24 \pm 0.02^{\mathrm{b}}$ & $1.30 \pm 0.02^{\mathrm{a}}$ \\
\hline Total production, $\mathrm{kg} / \mathrm{ha}^{\mathrm{F}}$ & $145.0 \pm 6.1^{\mathrm{a}}$ & $136.5 \pm 5.6^{\mathrm{a}}$ & $119.5 \pm 6.5^{\mathrm{b}}$ \\
\hline Cow requirements, $\mathrm{kg}$ TDN/210 days ${ }^{\mathrm{G} \#}$ & 935.7 & $1,098.4$ & $1,098.8$ \\
\hline Efficiency at 210 days, $\mathrm{kg} \mathrm{TDN}^{\mathrm{H} /}$ & 6.9 & 7.8 & 8.2 \\
\hline Efficiency performance, $\mathrm{Kg}$ TDN ${ }^{\mathrm{I} \#}$ & 9.1 & 10.3 & 11.0 \\
\hline Maintenance Crude protein, $\mathrm{kg} \mathrm{mCP} /$ day $^{\#}$ & 0.295 & 0.331 & 0.355 \\
\hline
\end{tabular}

* $(\mathrm{P}>0.05) ;{ }^{\mathrm{a}, \mathrm{b}, \mathrm{c}}$ Means on rows differ at $5 \%$ by t-test.

${ }^{\mathrm{A}}$ Calf weight at 210 days $\mathrm{x}$ pregnancy rate $/ 100=\mathrm{kg}$ of calf per cow kept in herds; ${ }^{\mathrm{B}}$ [(Calf weight at 210 days x pregnancy rate / 100) / cow weight at 210 days $=\mathrm{kg}$ of calf $/ \mathrm{kg}$ of cow at 210 days kept in herds; ${ }^{\mathrm{C}}$ Calf weight at 210 days / Cow weight at calving $* 100=\mathrm{kg}$ of calf $/ 100 \mathrm{~kg}$ of cow; ${ }^{\mathrm{D}}$ Calf weight at 210 days / Cow weight at 210 days $* 100=\mathrm{kg}$ of calf $/ 100 \mathrm{~kg}$ of cow; ${ }^{\mathrm{E}}$ (Cow weight + calf weight $) /(450 \mathrm{Kg} * 0.9 \mathrm{AU} / \mathrm{ha})=$ ha/for cow-calf; ${ }^{\mathrm{F}}$ (total cow weight gain + calf weight $) /$ real average load up to 210 days $=\mathrm{kg} / \mathrm{ha} ;{ }^{\mathrm{G}}$ Requirements TDN (kg/day) $* 210$ days; ${ }^{\mathrm{H}}$ Requirements in $\mathrm{kg}$ of TDN in 210 days / Calf weight at 210 days $=\mathrm{kg}$ TDN $/ \mathrm{kg}$ of calf; ${ }^{\mathrm{I}}$ Requirements in $\mathrm{kg}$ of TDN in 210 days / Calf weight gain in 210 days $=\mathrm{kg}$ TDN / calf weight at 210 days.

\# Adapted from NRC (2016).

The highest nutritional requirements of cows, as their body weight increases, determine higher TDN and $\mathrm{CP}$ expenses for the production of one kilogram of a calf. By comparing light cows to heavy cows, there is a need for $6.9 \mathrm{vs} .8 .2 \mathrm{~kg}$ of TDN, respectively, resulting in a $18.84 \%$ increase in nutrients. This increase is not reflected in calf weights at 210 days. The results show similarities between the demands of moderate and heavy cows (Table 2) justified by an increase in daily milk production and the weight gain of moderate cows. In contrast, light cows had
$14.78 \%$ less demands than moderate and heavy cows.

The production of milk up to 63 days postpartum was lower $(\mathrm{P}<0.05)$ for light cows than moderate cows, which did not differ from that of heavy cows $(\mathrm{P}>0.05)$. Even with a smaller size and subjected to the same feeding schedules as the other weight categories, the lower milk production of light cows did not influence the production of calves because the smaller frame of the animals was correlated with a lower milk consumption for conversion into 
kilograms of body weight. For Restle et al. (2004), genetic groups have less of an influence than food systems. The authors did not observe differences between Charolais and Nellore cows grazing on natural or cultivated pastures. However, when comparing food systems, animals kept in cultivated pastures produced $42.8 \%$ more calves than animals kept in natural pastures. Likewise, (VAZ et al., 2014) found that the calf production value for cows grazing on cultivated pastures $22.6 \%$ was higher than that of those kept only in natural pastures, with a herd efficiency of $57 \mathrm{vs} .37 \mathrm{~kg}$ of calf cow ${ }^{-1} \mathrm{kept}$ in herds.

There are differing results regarding the conversion of milk into calf weight gain. The quality and quantity of milk produced may be directly or indirectly influenced by collection methods (RODRIGUES et al., 2014), lactation period, production levels (VAZ et al., 2016; LEMES et al., 2017), and variations in the source of nutrients for the cow-calf pair (RESTLE et al., 2004). However, studies show that calf development and calf weight at weaning are a direct result of the milk production of their mothers (RODRIGUES et al., 2014).

To evaluate the productive system, it is necessary to consider the production by area. Heavy cows tend to produce heavier calves at weaning and slaughter, but the production per area may be smaller. To meet the needs of Heavy cows, more area is required. By associating the weights of cows and calves during lactation and calculating the consumption thereof, $1.07,1.24$, and 1.30 ha, respectively, are needed for an average lactation for light, moderate, and heavy cows, respectively.

Through the simulation of herds (Table 3), for an area of 500 ha, it is the possible to work with 420 , 368 , and 340 cows, for light, moderate, and heavy groups. Such values present a superiority of 14.1 and $23.5 \%$ of cows in the herds of light cows in relation to moderate and heavy cows, respectively. Even with a lower pregnancy rate $(\mathrm{P}>0.05)$, light cows produce a higher number of calves than moderate and heavy cows ( 246 vs 220 calves) due to a higher number of animals allocated in the same area. These two facts, when associated, are relevant because they are sources of income in breeding systems.

Table 3. Simulation, body weight production, and economic viability of Charolais cows of different sizes.

\begin{tabular}{lccc}
\hline \multirow{2}{*}{ Description } & \multicolumn{2}{c}{ Body structure } & Heavy \\
\cline { 2 - 4 } Cows & Animals, Numbers & Moderate & 340 \\
Bulls & 420 & 368 & 14 \\
Calves & 18 & 15 & 110 \\
Heifers & 123 & 110 & 110 \\
Replacement heifers & 123 & 110 & 75 \\
Herd total & 93 & 82 & 652 \\
& 781 & 688 & 68 \\
Cull cows & Sales, Numbers & 110 \\
Calves (males) & 84 & 74 & 35 \\
Cull heifers & 123 & 110 & 28 \\
Cull cows, kg & 30 & & 490 \\
Calves, kg & Sales, Weight & 135 \\
Cull heifers, kg & 400 & 450 & 120
\end{tabular}


continuation

\begin{tabular}{lccc} 
& Production of the system & \\
Production of cull cows, $\mathrm{kg}$ & 33,600 & 33,300 & 33,320 \\
Production of calves, $\mathrm{kg}$ & 16,605 & 15,510 & 14,850 \\
Production of cull heifers, $\mathrm{kg}$ & 3,600 & 3,500 & 4,200 \\
Total production of categories, $\mathrm{kg}$ & 53,805 & 52,310 & 52,870 \\
\hline
\end{tabular}

Studying the production efficiency at weaning of Nellore cows classified into six groups according to weight and considering a 59\% calving rate and a stocking capacity of $0.4 \mathrm{AU}^{-1}$, Silva et al. (2015) observed the same values for $\mathrm{kg}$ of cull cows per year when medium and heavy cows were compared. This is justified by the higher number of mediumsized than heavy animals allocated to the same area.

The total production of kilograms of animals represents the possible quantity of kilograms to be sold in the production systems. The commercially viable body weights were 53.085, 52.310, and $52.870 \mathrm{~kg}$ in herds of light, moderate, and heavy cows, respectively. Thus, they may remain stabilized, presenting the same number of animals over the years.

The total number of animals decreased among herds. The number for the weight groups was 781, 688, and 652 animals for light, moderate, and heavy cows, respectively. A high number of animals kept in a herd may lead to increased spending on the herd. This is contradictory because, although the components of variable costs may increase with the increase in the number of animals, such as fixeddose vaccines, independent of animal category, the costs of wormers, mineralization and food are proportional to animal weight.

Light and moderate cows obtained a higher total production by surface area. However, light cows were less nutritionally demanding during the 210 days. They were $13.19 \%$ more efficient at converting energy consumed into kilograms of calves produced (Table 2). In addition, to producing a higher number of kilograms of calves and cull cows, they generated a greater quantity of kilograms capable of being sold (Table 3).

The increase in the number of animals in herds, as well as the sale of a high total body weight, influences the economic results of the production system and plays a fundamental role in the dilution of the system's fixed costs, which represent $63.89 \%$ of the total spending for breeding systems with a $60 \%$ calving rate (GONÇALVES et al., 2017). The higher the revenue from the sale of breeding systems, the greater the dilution of fixed costs, provided they remain stable.

\section{Conclusion}

The size of Charolais cows did not affect the weight of calves from calving to 7 months of age. After 7 months, the daily weight variation was greater for animals born from larger cows.

The reproductive performance of Charolais cows is similar among different body sizes. When combining reproductive performance to production of calves as a function of $100 \mathrm{~kg}$ of cows kept in herds, light cows were more efficient at production both at calving and at 210 days. Moderate cows produced more milk up to 63 days postpartum than light cows. The area for the maintenance of the cowcalf pair increased with increases in cow weight. Maintaining small animal breeding herds allowed for a greater number of cows and production of kilograms for sale than maintaining herds of moderate and heavy cows. 


\section{References}

BARBOSA, P. F. Tamanho da estrutura corporal e desempenho produtivo de bovinos de corte. Revista Brasileira de Zootecnia, Viçosa, MG, v. 35, n. 3, p. 856878, 2006.

FAGUNDES, J. I. B.; LOBATO, J. F. P.; SCHENKEL, F. S. Efeito de duas cargas animais em campo nativo e de duas idades à desmama no desempenho de vacas de corte primíparas. Revista Brasileira de Zootecnia, Viçosa, MG, v. 32, n. 6, p. 1722-1731, 2003. Suplemento 1.

FERREIRA, M. C. N.; MIRANDA, R.; FIGUEIREDO, M. A.; COSTA, O. M. M.; PALHANO, H. B. Impacto da condição corporal sobre a taxa de prenhez de vacas da raça nelore sob regime de pasto em programa de inseminação artificial em tempo fixo (iatf). Semina: Ciências Agrárias, Londrina, v. 34, n. 4, p. 1861-1868, 2013.

GONÇALVES, G. V. B.; VAZ, R. Z.; VAZ, F. N.; MENDONÇA, F. S.; FONTOURA JUNIOR, J. A. S.; CASTILHO, E. M. Análise de custos, receitas e ponto de equilíbrio dos sistemas de produção de bezerros no rio grande do sul. Ciência Animal Brasileira, Goiânia, v. 18, n. 1, p. 1-17, 2017.

ÍTAVO, C.; EUCLIDES FILHO, K.; TORRES JÚNIOR, R. A. A.; ÍTAVO, C. C. B. F.; NOGUEIRA, E.; DIAS, A. M. Efficiency of calf production of cows from two genetic groups. Revista Brasileira de Zootecnia, Viçosa, MG, v. 43, n. 7, p. 390-394, 2014.

LEMES, J. S.; PIMENTEL, M. A.; VAZ, R. Z.; FARIAS, L. B.; BRAUNER, C. C. Performance efficiency of pasture-raised primiparous beef cows of three different biotypes and two milk production levels. Acta Scientiae Veterinariae, Porto Alegre, v. 45, n. 1, p. 1-8, 2017.

NATIONAL RESEARCH COUNCIL - NRC. Nutrient requirements of beef cattle. $8^{\text {th }}$ ed. Washington: National Academy Press, 2016. 494 p.

OWENS, F. N.; DUBESKI, P.; HANSONT, C. F. Factors that alter the growth and development of ruminants. Journal of Animal Science, Champaign, v. 71, n. 12, p. 3138-3150, 1993.

PILLAR, V. D. P.; MÜLLER, S. C.; CASTILHOS, Z. M. de S.; JACQUES, A. V. Á. Campos sulinos: conservação e uso sustentável da biodiversidade. Brasília: MMA, 2009. 403 p.

REGATIERI, I. C.; BOLIGON, A. A.; BALDI, F.; ALBUQUERQUE, L. G. Genetic correlations between mature cow weight and productive and reproductive traits in Nellore cattle. Genetics and Molecular Research, Ribeirão Preto, v. 11, n. 12, p. 2979-2986, 2012.
RESTLE, J.; PACHECO, P. S.; FREITAS, A. K.; BRONDANI, I. L.; PADUA, J. T.; FERNANDES, J. J. D. R.; ALVES FILHO, D. C. Influência das taxas de ganho de peso pré-desmame das vacas e do tipo de pastagem no período pós-parto sobre a eficiência biológica de vacas e de bezerros de corte. Revista Brasileira de Zootecnia, Viçosa, MG, v. 36, n. 4, p. 874-880, 2007.

RESTLE, J.; PACHECO, P. S.; PÁDUA, J. T.; GOMES, M.; VAZ, R. Z.; EIFERT, C.; MOLETTA, J. L.; FREITAS, A. K. Eficiência biológica de vacas de dois grupos genéticos amamentando bezerros puros ou F1, mantidas em diferentes condições de alimentação. Revista Brasileira de Zootecnia, Viçosa, MG, v. 33, n. 6 p. 1822-1832, 2004. Suplemento 1.

RIBEIRO, E. L. A.; RESTLE, J.; ROCHA, M. A.; MIZUBUTI, I. Y.; SILVA, L. D. F. Eficiência produtiva em vacas primíparas das raças aberdeen angus e charolês. Revista Brasileira de Zootecnia, Viçosa, MG, v. 30, n. 1, p. 125-132, 2001.

RODRIGUES, P. F.; MENEZES, L. M.; AZAMBUJA, R. C. C.; SUÑÉ, R. W.; BARBOSA SILVEIRA, I. D.; CARDOSO, F. F. Milk yield and composition from Angus and Angus-cross beef cows raised in southern Brazil. Journal Animal Science, Champaign, v. 92, n. 6, p. $2668-2676,2014$.

SANTOS, S. A.; ABREU, U. G. P.; SOUZA, G. S. E.; CATTO, J. B. Condição corporal, variação de peso e desempenho reprodutivo de vacas de cria em pastagem nativa no Pantanal. Revista Brasileira de Zootecnia, Viçosa, MG, v. 38, n. 2, p. 354-360, 2009.

SILVA, R. M.; SOUZA, J. C.; FERNANDES, H. J.; FERRAZ FILHO, P. B.; ROSA, A. N. Eficiência produtiva ao desmame de vacas Nelore criadas no Pantanal. Arquivo Brasileiro de Medicina Veterinária e Zootecnia, Belo Horizonte, v. 67, n. 4, p. 1105-1110, 2015.

SOUZA SILVA, G. E.; COSTA, E.; BERNARDO, F. A.; GROFF, F. H. S.; TODESCHINI, B.; SANTOS, D. V.; MACHADO, G. Panorama da bovinocultura no Rio Grande do Sul. Acta Scientiae Veterinariae, Porto Alegre, v. 42, n. 1, p. 1-7, 2014.

VAZ, R. Z.; LOBATO, J. F. P. Efeitos da idade de desmame no desempenho reprodutivo novilhas de corte expostas à reprodução aos 13/15 meses de idade. Revista Brasileira de Zootecnia, Viçosa, MG, v. 39, n. 1, p. 142150,2010 .

VAZ, R. Z.; LOBATO, J. F. P.; RESTLE, J. Productivity and efficiency of cow herds submitted to two weaning ages. Revista Brasileira de Zootecnia, Viçosa, MG, v. 39, n. 8 , p. $1849-1856,2010$. 
VAZ, R. Z.; RESTLE, J.; PACHECO, P. S.; VAZ, F. N.; ALVES FILHO, D. C.; BRONDANI, I. L.; PASCOAL, L. L.; ARGENTA, F. M. Produtividade e eficiência de produção de vacas de diferentes grupos genéticos submetidas a pastagens cultivadas no pré ou pós-parto. Semina: Ciências Agrárias, Londrina, v. 35, n. 5, p. 2697-2708, 2014.

VAZ, R. Z.; RIBEIRO, E. L. A.; RESTLE, J.; VAZ, F. N.; PACHECO, P. S.; MOLETTA, J. L. Productive efficiency of primiparous aberdeen angus cows of the different body sizes and milk production levels. Bioscinece Journal, Uberlândia, v. 32, n. 5, p. 1296-1304, 2016.

VIEIRA, A.; LOBATO, J. F. P.; TORRES, J. R. R. A. A.; CEZAR, I. M.; CORREA, E. S. Factors affecting the reproductive performance of nellore cows on the cerrado conditions of central Brazil. Revista Brasileira de Zootecnia, Viçosa, MG, v. 34, n. 6, p. 2408-2416, 2005. Suplemento. 
